\title{
Are Men More Vulnerable to Covid-19 as Compared to Women?
}

\author{
R Biswas* \\ Department of Physics, Applied Optics and Nanophotonics Lab, Assam, India \\ *Corresponding author: R Biswas, Applied Optics and Nanophotonics Lab, Department of Physics, Tezpur University, \\ Tezpur-784028, Assam, India
}

\begin{tabular}{|c|c|}
\hline ARTICLE INFO & ABSTRACT \\
\hline Received: 㓞 April 09, 2020 & \multirow{2}{*}{$\begin{array}{l}\text { Citation: R Biswas. Are Men More Vulnerable to Covid-19 as Compared to Women?. } \\
\text { Biomed J Sci \& Tech Res 27(2)-2020. BJSTR. MS.ID.004481. }\end{array}$} \\
\hline Published: 幽 April 28, 2020 & \\
\hline
\end{tabular}

\section{Mini Review}

Since the outbreak in Wuhan, China, the pandemic Covid 19 has caused a widespread damage to world economy. Most of the largest business enterprises are under locked down state. As per WHO guideline, there is Covid-19 advisory everywhere. It seems that the whole dynamism of human being has come to standstill. Until now, 15 million people has been affected worldwide. There is death report of more than $85 \mathrm{~K}$ people, which includes confirmed cases of all genres old, mid-aged, teenager and children including infants. However, when we look at the sex ratio of the deceased, a new trend emerges up. The death rates for men and women are not same. In most cases, men outshine women in terms of causalities. This brief communication tries to highlight the cases of sex ratio of death rates, along with plausible reasons behind such trend. Scientists used to figure out why Covid 19 affects more than women do. Data collected from Chinese death rates reveal that there exist a gender gap in causality rate. As per data, out of 100 patients, the no of male is 64 whereas the no. of females is 36 . As per [1,2], the male death rate stands at $4.7 \%$ for confirmed cases whereas female death rate stands at $2.8 \%$.

Even if the death rate apart from all cases is taken into account, the death rate for men exceeds that of the women. Not only in China, the same trend existed for Europe and South Korea. Figures from France, Germany, Italy, South Korea and Spain have confirmed the pattern. In the two hardest-hit European nations, the data reveal that around 29 percent of the Covid-19 deaths in Italy were female. The gruesome figures reveal a higher mortality for male [3]. Similarly, Spain registered two times more death rate for men as compared to women. Table 1 gives a brief outlook at the death rates of countries, which are hardest hit by Covid-19. It is quite evident that the death rate is following a pattern for all the countries; implying higher risks for men [4]. Although, it is too early to conclude. However, these data thrive researchers to make axioms about the reason behind such non-uniformity. From evolutionary perspective, men and women have different physiological attributes. They possess major structural differences in their bodies. It stems from tissues, organs and most importantly the immune system. In general, women tend to have greater immune response to a variety of viruses.

Table 1: Death rate for male and female of hardest hit countries [4].

\begin{tabular}{|c|c|c|}
\hline Country & Male & Female \\
\hline France & 58 & 42 \\
\hline Iran & 59 & 41 \\
\hline China & 64 & 36 \\
\hline Portugal & 64 & 36 \\
\hline Spain & 65 & 35 \\
\hline Germany & 66 & 34 \\
\hline Italy & 71 & 29 \\
\hline Denmark & 71 & 29 \\
\hline
\end{tabular}

In a recent study, scientists collected plasma samples of 331 patients who were Covid-19 positive. As an outcome of the study, some interesting facts emerged. Women contain more antibodies as compared which comparatively boost their immune system relative to men. Again, females possess estrogen as sex hormone, which gives them an upper hand than men. Studies suggest that estrogen acts as a shield against lot of viral infections. In another study, females also owns two X chromoomes. Consequently, they attain a extra copy of gene so as to elevate the immune system. On 
the other hand, due to esxistence of two different chromosomes $\mathrm{X}$ and $\mathrm{Y}$, men do not have this merit. Meanwhile, the no of smoke as well as alcohol addicts are quite large in case of men as per worldwide statistics. This puts them a higher risk of lung cancer and other cardio vascular diseases. As it is known that SARSCOVID-2 potentially attacks the lungs, hence, the mortality rate goes up. Apart from this, men are less likely to maintain hygiene as compared to women. The reluctance of using a hand wash or sanitizer as a precautionary measure for Covid 19 in men cannot be ruled out. Not only that, they are less likely to seek medical attention although vital symptoms emerge. They in general approach doctor when condition worsens which totally aggravates the situation. In such cases, women are found to be proactive as compared to them. In another comparative fact, it is established that the gut bacteria possessed by men and women differs in lot of aspects. These gut

ISSN: 2574-1241

DOI: 10.26717/BJSTR.2020.27.004481

R Biswas. Biomed J Sci \& Tech Res

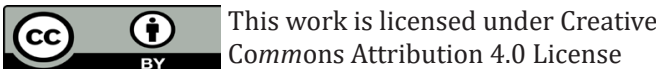

Submission Link: https://biomedres.us/submit-manuscript.php bacteria play a crucial role in our immune response. Additionally, females are in possession of specific microbiome that functions as extra protection measure. Now, as the epidemic is still on; more and more data will emerge. Accordingly, scientists around the world are urging all sources to share them with the recent statistics which will help them to formulate vaccine for combating the ongoing Covid-19.

\section{References}

1. (2020) The Epidemiological Characteristics of an Outbreak of 2019 Novel Coronavirus Diseases (COVID-19) - China CCDC.

2. (2020) Report of the WHO-China Joint Mission on Coronavirus Disease 2019 (COVID-19) - World Health Organization, Geneva.

3. https://www.france24.com/en/20200331-coronavirus-why-do-moremen-die-of-covid-19-than-women

4. https://www.statista.com/chart/21345/coronavirus-deaths-bygender/

$\begin{array}{ll}\text { BIOMEDICAL } & \text { Assets of Publishing with us } \\ \text { RESEARCHES } & \text { - Global archiving of articles } \\ & \text { - Immediate, unrestricted online access } \\ \end{array}$

